\title{
Microbiological status of root canal after unsuccessful endodontic treatment
}

\author{
Jelena Nešković', Milica Jovanović-Medojević', Đurica Grga', Branka Popovic², Slavoljub Živković1 \\ 'University of Belgrade, School of Dental Medicine, Department of Restorative Odontology and Endodontics, Belgrade, \\ Serbia; \\ ${ }^{2}$ University of Belgrade, Institute of Human Genetics, School of Dental Medicine, Belgrade, Serbia
}

\begin{abstract}
SUMMARY
Introduction The main objective of endodontic treatment is to eliminate infection from root canal and prevent reinfection by three-dimensional hermetic obturation of the canal system. Endodontic failure can occur due to inability of complete control and elimination of infection from the root canal.

The aim of this study is to investigate, by PCR technique, microbiological status of previously endodontically unsuccessfully treated teeth immediately after the removal of obturation material.

Material and Methods The analysis included 30 teeth indicated for endodontic retreatment. After removing previous root canal filling material, the bacteriological sample was taken by sterile instrument (\# 15) and paper points. Standard PCR technique was used to analyze the incidence of E.faecalis, P.micros, P.intermedia, P. endodontalis and A.actinomycetemcomitans.

Results Positive bacteriological findings were registered in $80 \%$ of cases, while bacteria were not identified in $20 \%$ of all samples (all taken from the root canals without significant changes in periapical tissue). From 24 canals with identified bacteria, 17 had affected apical periodontium. The most dominant microbe in root canals with positive bacteriological finding was E.faecalis ( $83.3 \%$ of the canals) and P.intermedia (75\%). In case of teeth with chronic periapical changes, the most common was E. faecalis (94\%) and P.intermedia (82.3\%).

Conclusion The presence of periapical lesions significantly affects microbiological status of endodontically treated teeth. The presence of bacteria was confirmed in most teeth with periapical lesions, while the most frequently identified bacteria were E. faecalis, P.intermedia and P.micros.

Keywords: PCR; E. faecalis; endodontic failure
\end{abstract}

\section{INTRODUCTION}

The main objective of endodontic treatment is to eliminate infection from the root canal and prevent reinfection by three-dimensional hermetic obturation of the canal system. However, sometimes even properly conducted endodontic treatment can fail. It has been confirmed that the outcome of endodontic treatment depends largely on the quality of endodontic procedures and possibility of eliminating infection from root canal system before obturation $[1,2]$. Due to the complexity of canal systems their cleaning is difficult, therefore bacteria may remain in inaccessible parts of the canal, especially in the apical portion.

Persistant infection in the apical third is most often result of inadequate completion of endodontic treatment i.e. non-aseptic conditions with insufficiently extended and poorly designed access cavities, insufficient dimension of instrumentation, inadequate hermetic obturation or microleakage due to inadequate temporary or definitive restorations [3]. However, number of infections may persist as asymptomatic periapical radiolucency even if endodontic procedure is properly implemented. The reason is usually complex anatomy of the root canal system with regions that cannot be adequately treated and obturated by existing instruments, materials and techniques [4]. Some studies have shown that certain parts of the root canal space remain untouched during chemo-mechanical instrumentation regardless of the preparation technique or instruments used [5]. Untreated parts of the root canal can contain bacteria and necrotic tissues even when obturation seems to be radiographically correct [4]. It is believed that endodontic failure is caused by inability of complete control and elimination of infection in the root canal.

The aim of this study was, using PCR technique, to investigate microbiological status of endodontically treated teeth with persistent infection immediately after the removal of obturation material.

\section{METHODS}

Material for microbiological tests was obtained by taking samples from 30 patients who had root canal treatment done earlier but they needed retreatment. After obtaining dental history, and taking periapical radiographs, patients 
were clinically examined and failure of the initial endodontic treatment was diagnosed.

Microbiological study included 30 teeth $(8$ multirooted and 22 single-rooted) indicated for endodontic retreatment. Primary endodontic therapy was performed 12 months ago in 2 cases, $1-5$ years in 8 cases, while for 20 teeth, primary endodontic treatment was done $>5$ years ago. All 30 teeth had inadequate obturation and that was the failure criterion for which patients needed retreatment. Poor quality of obturation was assessed as short filling (in 22 teeth), "forgotten" canal (in 7 teeth), or separated instrument (in 1 tooth). Adequate restoration or prosthetic restorations (crowns) were observed in 13 teeth, 7 teeth were without coronal restoration for a longer period of time and 10 teeth did not have proper restoration. The presence of symptoms such as pain, swelling, presence of a fistula, sensitivity to percussion or pain when biting were observed in 10 patients, while the remaining 20 had no clinical signs or symptoms.

Status of apical periodontal tissue was evaluated by PAI index, where completely healthy periodontium (PAI 1) was radiographically registered in 6 cases; PAI 2 score (small changes in the bone structure that are not pathognomonic for apical periodontitis) was recorded in 7 cases; PAI 3 score (which includes changes in bone structure with decalcification characteristic for apical periodontitis) was registered in 13 teeth; PAI 4 (which represents periodontitis with clearly defined zone of radiolucency) was noted in 3 cases; the highest score of PAI 5 (advanced periodontitis with signs of exacerbation and expansion of the bone), was registered only in 1 case. Microbiological process involved first the removal of hard and soft deposits from teeth, restorations and decay and placing a rubber dam. Disinfection of the operative field was done with 30\% hydrogen peroxide solution and $2.5 \%$ sodium hypochlorite solution, which is then inactivated with $5 \%$ sodium thiosulfate. Previous root canal filling material was removed without the use of any solvents, fillers, lubricants or irrigants. Gates Glidden drills were used to remove gutta-percha from the first two-thirds of the root canal, and Hedstrom files were used for the apical third of the root canal. During radiographic determination of working length, the quality of removal of obturation material was checked. Working length was determined with apex locator. In cases of forgotten canals, access cavity was extended, oriphicies located, and root canals were in- strumented by modified double-cone technique - Gates Glidden drills, hand Hedstrom and K-Flex files to full working length. The size of apical preparation (ISO \# 25 or \# 30) depended on initial diameter and curvature of the root canal. Then after small amount of sterile saline was placed in the root canal and further instrumented in order to scrape the material from the canal walls. The sample was taken using sterile canal instrument - barbed broach type (\# 15) or Hedstrom files (\# 15) with the help of paper points that were used to dry the canal. The paper points were placed with sterile forceps and left in the canal for 60 seconds and then placed in sterile micro-tubes together with canal instruments whose handle was cut off with sterile forceps. The micro-tubes were stored at the temperature of $-20^{\circ} \mathrm{C}$ until microbiological analysis.

With the aim to isolate DNA, $100 \mathrm{ml}$ of redistilled water was added in each micro-tube with paper points. Isolation of total bacterial DNA (Gram positive and Gram negative bacteria) was performed using commercial kit QIAamp DNA Mini Kit (Qiagen). After application of isolation protocol, bacterial DNA was dissolved in 100 $\mathrm{ml}$ of elution buffer.

The incidence of the following bacteria was analyzed by classical PCR: Enterococcus faecalis, Peptostreptococcus micros, Porphyromonas endodontalis and Actinobacillus actinomycetemcomitans. The sequences of used primers; the temperature profile and length of PCR products are shown in Table 1. In each PCR reaction, simultaneously with the test samples, positive and negative controls were used to avoid false positive and negative results. Reaction mixture of PCR with $25 \mathrm{ml}$ volume was made up of

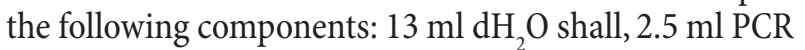
buffer, $1.5 \mathrm{ml}$ of $25 \mathrm{mM} \mathrm{MgCl}, 1 \mathrm{ml}$ of dNTP, per $1 \mathrm{ml}$ of $F$ and $\mathrm{R}$ primers, $0.2 \mathrm{ml}$ of Taq polymerase and $5 \mathrm{ml}$ bacterial DNA.

The effectiveness of PCR reaction was measured by electrophoresis on a vertical $8 \%$ polyacrylamide gel (PAA) in 1XTBE buffer, at constant voltage of $200 \mathrm{~V}$ for a period of $30 \mathrm{~min}$. Visualization of PCR products was performed by staining with ethidium bromide.

\section{RESULTS}

PCR technique was used to analyze the presence of the following microorganisms: E. faecalis, P. micros, $P$. inter-

Table 1. Primer sequences, specific hybridization temperature and length of PCR products

Tabela 1. Sekvence prajmera, specifične temperature hibridizacije i dužine PCR produkata

\begin{tabular}{|c|c|c|c|}
\hline $\begin{array}{l}\text { Microorganism } \\
\text { Mikroorganizam }\end{array}$ & $\begin{array}{l}\text { Primer } \\
\text { Prajmer }\end{array}$ & $\begin{array}{l}\text { Temperature Profile } \\
\text { Temperaturni profil }\end{array}$ & $\begin{array}{l}\text { PCR Product } \\
\text { PCR produkt }\end{array}$ \\
\hline $\begin{array}{l}\text { Enterococcus } \\
\text { faecalis }\end{array}$ & $\begin{array}{l}\text { F,TACTGACAAACCATTCATGATG } \\
\text { R, AACTTCGTCACCAACGCGAAC }\end{array}$ & \multirow{5}{*}{$\begin{array}{l}95^{\circ} \mathrm{C} 3 \mathrm{~min} \\
95^{\circ} \mathrm{C} 45 \mathrm{~s}, \\
55^{\circ} \mathrm{C} 1 \mathrm{~min}, \\
72^{\circ} \mathrm{C} 1 \mathrm{~min}, \\
\times 35 \mathrm{cyclus} \\
72^{\circ} \mathrm{C} 5 \mathrm{~min}\end{array}$} & $112 b p$ \\
\hline $\begin{array}{l}\text { Peptostreptococcus } \\
\text { micros }\end{array}$ & $\begin{array}{l}\text { F, AGAGTTTGATCCTGGCTCAG } \\
\text { R,ATATCATGCGATTCTGTGGTCTC }\end{array}$ & & $207 b p$ \\
\hline Prevotela intermedia & $\begin{array}{l}\text { F,CGTGGACCAAAGATTCATCGGTGGA } \\
\text { R, CCGCTTTACTCCCCAACAAA }\end{array}$ & & 259bp \\
\hline $\begin{array}{l}\text { Porphyromonas } \\
\text { endodontalis }\end{array}$ & $\begin{array}{l}\text { F, GCTGCAGCTCAACTGTAGTC } \\
\text { R, CCGCTTCATGTCACCATGTC }\end{array}$ & & $672 b p$ \\
\hline $\begin{array}{l}\text { Actinobacilus } \\
\text { actinomycetemcomitans }\end{array}$ & $\begin{array}{l}\text { F, GCTAATACCGCGTAGAGTCGG } \\
\text { R, ATTTCACACCTCACTTAAAGGT }\end{array}$ & & $500 \mathrm{bp}$ \\
\hline
\end{tabular}


Table 2. The presence of bacteria in the sample in relation to the status of apical periodontium

Tabela 2. Prisustvo bakterija u uzorku u odnosu na stanje apeksnog parodoncijuma

\begin{tabular}{|c|c|c|c|c|c|}
\hline \multirow{2}{*}{$\begin{array}{l}\text { Status of Periodontium } \\
\text { Stanje parodoncijuma }\end{array}$} & \multicolumn{2}{|c|}{$\begin{array}{l}\text { Negative bacteriological findings } \\
\text { Negativan bakteriološki nalaz }\end{array}$} & \multicolumn{2}{|c|}{$\begin{array}{l}\text { Positive bacteriological findings } \\
\text { Pozitivan bakteriološki nalaz }\end{array}$} & \multirow{2}{*}{$\begin{array}{l}\text { Total } \\
\text { Ukupno }\end{array}$} \\
\hline & $\mathrm{N}$ & $\%$ & $N$ & $\%$ & \\
\hline $\begin{array}{l}\text { Healthy periodontium } \\
\text { Zdrav parodoncijum } \\
\text { PAI } 1,2\end{array}$ & 6 & $20 \%$ & 7 & $23.3 \%$ & 13 \\
\hline $\begin{array}{l}\text { Chronic apical periodontitis } \\
\text { Hronični apikalni periodontitis } \\
\text { PAI } 3,4,5\end{array}$ & 0 & 0 & 17 & $56.6 \%$ & 17 \\
\hline$\Sigma$ & 6 & $20 \%$ & 24 & $80 \%$ & 30 \\
\hline
\end{tabular}

Table 3. The presence of bacterial species in the tested samples of root canals

Tabela 3. Zastupljenost bakterijskih vrsta u testiranim uzorcima kanala

\begin{tabular}{|l|c|c|}
\hline $\begin{array}{l}\text { Microorganism } \\
\text { Vrsta bakterije }\end{array}$ & N & $\%$ \\
\hline E. faecalis & 20 & $66.6 \%$ \\
\hline P. micros & 14 & $46.6 \%$ \\
\hline P. endodontalis & 8 & $26.6 \%$ \\
\hline P. intermedia & 18 & $60 \%$ \\
\hline A. actinomycetemcomitans & 3 & $10 \%$ \\
\hline
\end{tabular}

Table 4. The presence of bacterial species in relation to the apical periodontal condition

Tabela 4. Zastupljenost bakterijskih vrsta u odnosu na stanje apeksnog parodoncijuma

\begin{tabular}{|c|c|c|c|c|c|c|}
\hline \multirow[t]{2}{*}{ 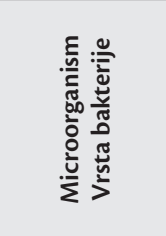 } & \multicolumn{2}{|c|}{$\begin{array}{l}\text { Teeth with healthy } \\
\text { periodontium } \\
\text { (PAI 1,2) } 7 \text { teeth } \\
\text { Zubi sa zdravim } \\
\text { parodoncijumom } \\
\text { (PAI 1,2) } 7 \text { zuba }\end{array}$} & \multicolumn{2}{|c|}{$\begin{array}{c}\text { Teeth with } \\
\text { periapical lesions } \\
(\text { PAI } 3,4,5) 17 \text { teeth } \\
\text { Zubi sa periapi- } \\
\text { kalnim lezijama } \\
(\mathrm{PAI} 3,4,5) 17 \text { zuba }\end{array}$} & \multicolumn{2}{|c|}{$\begin{array}{l}\text { Total of } \\
24 \text { teeth } \\
\text { Ukupno } \\
24 \text { zuba }\end{array}$} \\
\hline & $\mathbf{N}$ & $\%$ & $\mathbf{N}$ & $\%$ & $\mathbf{N}$ & $\%$ \\
\hline E. faecalis & 4 & $57 \%$ & 16 & $94 \%$ & 20 & $83.3 \%$ \\
\hline P. micros & 4 & $57 \%$ & 10 & $58.8 \%$ & 14 & $58.3 \%$ \\
\hline P. endodontalis & 4 & $57 \%$ & 4 & $23.5 \%$ & 8 & $33.3 \%$ \\
\hline P. intermedia & 4 & $57 \%$ & 14 & $82.3 \%$ & 18 & $75 \%$ \\
\hline $\begin{array}{l}\text { A. actinomy- } \\
\text { cetemcomitans }\end{array}$ & 0 & 0 & 3 & $17.6 \%$ & 3 & $12.5 \%$ \\
\hline
\end{tabular}

Table 5. Distribution of the number of bacterial species in individual samples

Tabela 5. Distribucija broja bakterijskih vrsta u pojedinačnim uzorcima

\begin{tabular}{|c|c|c|}
\hline $\begin{array}{l}\text { Number of species per sample } \\
\text { Broj vrsta u uzorku }\end{array}$ & N & $\%$ \\
\hline 0 & 6 & 20 \\
\hline 1 & 4 & 13.3 \\
\hline 2 & 6 & 20 \\
\hline 3 & 10 & 33.3 \\
\hline 4 & 3 & 10 \\
\hline 5 & 1 & 3.3 \\
\hline
\end{tabular}

media, P. endodontalis and A. actinomycetemcomitans. Positive bacteriological findings were registered in $80 \%$ of cases, while the bacteria were not identified in $20 \%$ of samples. All negative samples were taken from the root canal without significant changes in the apical periodontal tissue (PAI 1,2) while 17 out of 24 canals with identified bacteria belonged to the teeth with damaged apical periodontium (PAI 3, 4, 5) (Table 2). All samples taken from the root canals with chronic periapical lesions were positive for bacteria (100\%).
Table 6. The presence of bacterial species in tested samples in relation to the state of the apical periodontium (PAI index)

Tabela 6. Zastupljenost bakterijskih vrsta u testiranim uzorcima u odnosu na stanje apeksnog parodoncijuma (PAI index)

\begin{tabular}{|c|c|c|c|c|c|c|c|c|}
\hline $\begin{array}{r}\text { PAIN } \\
\text { of species }\end{array}$ & & 1 & 2 & 3 & 4 & 5 & \multicolumn{2}{|c|}{$\begin{array}{c}\text { Total } \\
\text { Ukupno }\end{array}$} \\
\hline & $\mathrm{N}$ & 6 & 7 & 13 & 3 & 1 & \multirow{2}{*}{$\mathrm{N}$} & \multirow[t]{2}{*}{$\%$} \\
\hline Broj vrsta & $\%$ & 20 & 23.3 & 43.3 & 10 & 3.3 & & \\
\hline \multirow{2}{*}{0} & $\mathrm{~N}$ & 5 & 1 & & & & \multirow{2}{*}{6} & \multirow[t]{2}{*}{20} \\
\hline & $\%$ & 16.6 & 3.3 & & & & & \\
\hline \multirow{2}{*}{1} & $\mathrm{~N}$ & 1 & 2 & 1 & & & \multirow{2}{*}{4} & \multirow[t]{2}{*}{13.3} \\
\hline & $\%$ & 3.3 & 6.6 & 3.3 & & & & \\
\hline \multirow{2}{*}{2} & $\mathrm{~N}$ & & 1 & 4 & 1 & & \multirow{2}{*}{6} & \multirow[t]{2}{*}{20} \\
\hline & $\%$ & & 3.3 & 13.3 & 3.3 & & & \\
\hline \multirow{2}{*}{3} & $\mathrm{~N}$ & & 3 & 7 & & & \multirow{2}{*}{10} & \multirow[t]{2}{*}{33.3} \\
\hline & $\%$ & & 10 & 23.3 & & & & \\
\hline \multirow{2}{*}{4} & $\mathrm{~N}$ & & & & 2 & 1 & \multirow{2}{*}{3} & \multirow[t]{2}{*}{10} \\
\hline & $\%$ & & & & 6.6 & 3.3 & & \\
\hline \multirow{2}{*}{5} & $\mathrm{~N}$ & & & 1 & & & \multirow{2}{*}{1} & \multirow[t]{2}{*}{3.3} \\
\hline & $\%$ & & & 3.3 & & & & \\
\hline
\end{tabular}

Isolated bacteria mainly belonged to E. faecalis (66.6\%) followed by P.intermedia (60\%), P. micros (46.6\%), P. endodontalis (26.6\%) and A. actinomycetemcomitans (10\%) (Table 3).

The most dominant microorganism in root canals with positive bacteriological findings was E.faecalis (83.3\%), followed by P. intermedia (75\%) and P.micros (58.3\%) (Table 4). In the group of teeth with healthy apical pericapical tissue, all bacterial species (except A. actinomycetemcomitans which was not detected in any of the samples) were equally represented or were identified in $57.7 \%$ of canals. In the case of teeth with chronic periapical changes, the most common isolation was $E$. faecalis identified in $94 \%$ of the canals, then Pintermedia that was present in $82.3 \%$ of samples (Table 4).

In regards to the number of bacterial species contained in a single sample, monoinfection was registered in 13.3\% of cases (E.faecalis was presented in half of the canals), while the most common bacteria identified in $33.3 \%$ of canals were 3 bacterial species per one canal E. faecalis, P. intermedia and P.micros (Table 5). It was observed that the samples taken from the tooth with healthy periodontal tissues around the root tip, showed mainly absence of bacteria or the presence of 1 or 2 bacterial species, while in the case of chronic periapical changes, in more than a half of samples, the presence of 3 or more bacterial species was identified (Table 6). 
Table 7. Distribution of bacteria in correlation with the presence of certain symptoms

Tabela 7. Distribucija bakterija u odnosu na prisustvo određenih simptoma

\begin{tabular}{|c|c|c|c|c|c|c|c|c|c|c|}
\hline \multirow{2}{*}{$\begin{array}{l}\text { Symptom } \\
\text { Simptom } \\
\text { Microorganism } \\
\text { Mikroorganizam }\end{array}$} & \multicolumn{2}{|c|}{$\begin{array}{l}\text { Pain } \\
\text { Bol }\end{array}$} & \multicolumn{2}{|c|}{$\begin{array}{l}\text { Swelling } \\
\text { Otok }\end{array}$} & \multicolumn{2}{|c|}{$\begin{array}{l}\text { Sinus tract } \\
\text { Fistula }\end{array}$} & \multicolumn{2}{|c|}{$\begin{array}{l}\text { Percution sensitivity } \\
\text { Perkutorna osetljivost }\end{array}$} & \multicolumn{2}{|c|}{$\begin{array}{c}\text { Pain when biting } \\
\text { Bol na zagrižaj }\end{array}$} \\
\hline & $\mathrm{N}$ & $\%$ & $\mathrm{~N}$ & $\%$ & $\mathrm{~N}$ & $\%$ & $\mathrm{~N}$ & $\%$ & $\mathrm{~N}$ & $\%$ \\
\hline E. faecalis & 3 & 100 & 1 & 50 & 1 & 50 & 8 & 100 & 3 & 100 \\
\hline P. micros & 2 & 66.6 & 1 & 50 & 1 & 50 & 4 & 50 & 1 & 33.3 \\
\hline P. endodontalis & 1 & 33.3 & & & & & 2 & 25 & & \\
\hline P. intermedia & 3 & 100 & 1 & 50 & 1 & 50 & 8 & 100 & 3 & 100 \\
\hline A. actinomycetemomitans & & & & & 1 & 50 & 1 & 12.5 & 1 & 33.3 \\
\hline $\begin{array}{l}\text { Number of patients with symptoms } \\
\text { Broj pacijenata sa simptomima }\end{array}$ & 3 & & 2 & & 2 & & 8 & & 3 & \\
\hline
\end{tabular}

Correlation between the presence of certain symptoms after the initial endodontic treatment and findings of specific bacterial species in root canal are shown in Table 7. E. faecalis and P. intermedia were detected in all patients with pain, teeth sensitive to percussion and pain when biting, as well as the half of the samples taken from the root canal with sinus tract and swelling. P.micros was identified in $66.6 \%$ of patients with pain, $50 \%$ of patients with swelling, sinus tract and percussion sensitivity and $33.3 \%$ of patients with pain when biting. The presence of P. endodontalis was confirmed in $33.3 \%$ of the canals registered with spontaneous pain and $25 \%$ with sensitivity to percussion. A. actinomycetemcomitans was identified in $50 \%$ of the canals with sinus tract, $33.3 \%$ of patients with pain when biting and $12.5 \%$ of the samples taken from the root canal of patients with sensitivity to percussion (Table 7).

\section{DISCUSSION}

The analysis included 30 teeth that needed retreatment regardless of its causes - prosthetic indications, incidental finding or the patient reported having problems. In order to prevent contamination of canal samples, strictly aseptic conditions were conducted by the current protocol for disinfection of working fields [6-9]. This involved decontamination and disinfection of the operative field with $30 \%$ hydrogen peroxide solution and $2.5 \%$ sodium hypochlorite followed by inactivation of $5 \%$ sodium thiosulfate so that its remains would not affect the sample taken [7]. Also, complete removing of the root canals filings was done purely mechanically without use of any solvents, lubricants or irrigants. The micro-tubes with microbiological material were stored at $-20^{\circ} \mathrm{C}$, for no longer than a month.

PCR (Polymerase Chain Reaction) is a modern, fast (it takes a few hours), and a simple method for identification of microorganisms. It is extremely sensitive and highly specific. Theoretically, it is possible to demonstrate the presence of only single bacterial cell (living or dead) in the sample, although the number of 10 cells is considered to be the lowest limit for detection (e.g. 100 viable cells are necessary for one method of bacteria cultivation) [9]. Identification is based on in vitro amplification of target DNA fragment, which can be repeated up to a billion times. Because its detection works on the basis of genotypic structure, rather than phenotypic characteristics of microorganisms, identification is very reliable and precise. It is possible to identify those bacterial species that cannot be cultivated in vitro or cases where the number of cells in examined material is very small [9]. However, the PCR method of identification of microorganisms has its limitations. Firstly, the species that are not targeted or detected by other methods cannot be identified. Precisely determined conditions are required for reaction with specific primer pair that can detect only particular and specific bacterial species. It should be noted that PCR method can not determine if identified cell is alive or dead. Another limitation of the conventional PCR method is its inability to quantify the number of bacteria. This can be overcome by "real-time" PCR method where the number of bacterial cells can be determined [10].

Positive bacteriological findings were registered in $80 \%$ of cases, while no bacteria were identified in $20 \%$ of samples. All samples taken from root canals with chronic periapical lesions were positive for presence of bacteria (100\%). Also, all negative samples were taken from root canal with healthy periapical tissue. This confirmed the hypothesis that without bacteria, there is no infection in periapical tissues, and consequently there is no failure of endodontic treatment. Similar results were obtained by Siqueira et al. [5], Gomes et al. [11,12], Roca et al. [13], Sedgley et al. [14] and Sakamoto et al. [15].

However, $23 \%$ of positive bacteriological samples were taken from root canals where periapical tissue had PAI score 2 (periapical radiolucency) with no pathognomonic signs of chronic inflammation. Kaufman et al. [16] and Olette et al. [17] reported the presence of bacteria in the root canal without any periapical changes detected radiographically. The explanation may lie in the fact that two-dimensional radiography is not sufficiently accurate to diagnose apical periodontitis with less destroyed bone tissue [18]. Also, it could be that small number and low virulent bacteria are present. Only if present in higher numbers and pathogenic bacteria persisting after primary endodontic treatment can cause or maintain periradicular inflammation [2]. However, there is a dilemma whether bacteria remained after primary endodontic treatment (persistent infection) or they are the result of re-infection (secondary infection). In the recent years, research has pointed out the importance of proper coronal restora- 
tion in preventing re-infection of endodontic space with opinion that secondary infection is important cause of endodontic treatment failure $[1,19]$. The most common microorganism in the canal system with positive bacteriological findings was $E$. faecalis followed by $P$. intermedia and $P$. micros accounting for $58.3 \%$. E. faecalis was identified in $94 \%$ of root canals with chronic periapical lesions (PAI 3, 4,5) which is similar to findings of Sedgley et al. who also used PCR identification method. They used 48 samples and showed that the incidence of $E$. faecalis finding was 90\% [14]. Gomes et al. used PCR to analyze microbiological status of previously filled canals with periapical lesions and came to the conclusion that E. faecalis was present in $90 \%$ of bacteriologically positive root canals followed by P. micros 59\%, P. gingivalis 41\%, P. endodontalis $26 \%$ and $P$. intermedia $13 \%$ [12]. This high percentage of $E$. faecalis was probably the result of its numerous and diverse virulence factors and extraordinary ability to survive. This microorganism is small; it easily penetrates into dentinal tubules and has a good adherence to collagen [20]. It is resistant to calcium hydroxide [21] and has the ability to survive (as a single species) in dentinal tubules without the support of other bacteria [22]. Also, it has the ability to survive without nutrients and recover easily when they become available in the form of serum (the origin of alveolar bone and periodontal ligament) [23].

The results of this study confirmed the presence of $E$. faecalis in $57.7 \%$ of root canals without changes in apical periodontal tissue. However, P. intermedia, P. endodontalis and $P$. micros were also identified in $57.7 \%$ of root canals which leads to the conclusion that E. faecalis is not the only microorganism responsible for failure of endodontic treatment. Williams et al. showed that $E$. faecalis can survive all stages of endodontic treatment because RT-PCR detected its presence in samples taken immediately after instrumentation and irrigation as well as after medication [24].

Our research indicated that remaining microorganisms could be present in root canals due to inadequate coronal seal. In $70 \%$ of teeth with healthy periodontal apical tissue, coronal restoration did not show satisfactory quality that opened door for secondary infection of endodontic space. In addition, although present in root canal, the bacteria had no effect on periapical tissue. They probably remained blocked and trapped in dentinal tubules or root canal filling material blocked further progress to periapical tissues (microleakage).

Patients who took part in our study came from general dental practice and health centers where it was quite difficult to adhere to contemporary standards and good endodontic practice, therefore the incidence of residual bacteria after primary endodontic treatment was high. Prevotella spp and Porphiromonas spp (previously classified as Bacteroides spp) belong to the group of "blackpigmented bacteria" because in contact with agar, they form shiny, smooth colonies of gray or black. According to the new taxonomy, saharolytic Bacteroides spp species are classified as genus Prevotella, while asaharolytic species belong to genus Porphiromonas. Types of $P$. intermedia, $P$. melaninogenica, $P$. denticola and $P$. dentalis belong to gram-negative obligate anaerobes. Although they have limited ability of fermentation of amino acids and require the presence of hemin and menadione for growth, they can be observed in different parts of body (oral cavity, upper respiratory and urogenital system) [25]. Ruan et al. found that $P$. intermedia originating from oral cavity represents potential opportunistic microorganism associated with periodontal disease but also apical periodontitis due to its adhesiveness and competitiveness with surrounding microorganisms [25].P. endodontalis is gram-negative microorganism associated with periodontitis, endodontic infections and gingivitis, and more frequently with symptomatic than asymptomatic infections in oral cavity [26].

One-third of patients who took part in the current study showed some clinical symptoms, but the most common symptom was sensitivity to percussion. The most common microorganisms present in the samples taken from such teeth were E. faecalis and P. intermedia (100\%), followed by P. micros (50\%). Gomes et al. also found statistically significant relationship between P.micros and tooth sensitivity to percussion [12] while Pinheiro et al. noticed association between P.intermedia and the presence of these symptoms [27]. E.faecalis and P.intermedia were detected in all patients with pain, tenderness to percussion and pain when biting, as well as one half of the samples taken from root canals of patients with swelling and fistula. P. micros was identified in $66.6 \%$ of patients with pain that is in accordance with the study of Pinheiro et al. who reported involvement of bacterial species P.intermedia and P.micros in teeth where pain was present [27].

\section{CONCLUSION}

The presence of periapical lesions significantly affects microbiological status of endodontically treated teeth. The presence of bacteria in root canals was confirmed in most cases of unsuccessful endodontic treatments, while the most frequently identified bacteria were E. faecalis, followed by P. intermedia, P. micros and P. endodontalis.

\section{REFERENCES}

1. Ray HA, Trope M. Periapical status of endodontically treated teeth in relation to the technical quality of the root filling and the coronal restoration. Int Endod J. 1995; 28:12-8. [PMID: 7642323]

2. Siqueira JF. Aethiology of root canal treatment failure: why welltreated teeth can fail. Int Endod J. 2001; 34:1-10. [PMID: 11307374]

3. Nair PNR. On the causes of persistent apical periodontitis: a review. Int Endod J. 2006; 39: 249-81.

[DOI: 10.1111 / j.1365-2591.2006.01099.x]

4. Nair PNR, Henry S, V Cano, Vera J. Microbial status of apical root canal system of human mandibular first molars with primary apical periodontitis after "one-visit" endodontic treatment. Oral Surg Oral Med Oral Pathol Oral Radiol Dent. 2005; 99:231-52. [DOl: 10.1016/ j.tripleo.2004.10.005] [PMID: 15660098]

5. Siqueira JFJr, Rocas IN. Polymerase chain reaction-based analysis of microorganisms associated with failed endodontic treatment. Oral Surg Oral Med Oral Pathol Oral Radiol Dent. 2004; 97:85-94. [DOI: 10.1016 / S1079210403003536] [PMID: 14716262 ] 
6. Friedman S, Mor Ch. The success of endodontic therapy-and healing functionality. CDA I 2004; 32:493-503. [PMID: 15344440]

7. Ng Y-L, Spratt D, Sriskantharajah S, Gulabivala K. Evaluation of protocols for field decontamination before bacterial sampling of root canals for contemporary microbiological techniques.) Endod 2003; 29: 317-332. [DOI: 10.1097/00004770-200305000-00001] [PMID: 12775002]

8. Sundquist G, Figdor D, Persson S, Sjögren U. Microbiologic analysis of teeth with failed endodontic treatment and the outcome of conservative retreatment. Oral Surg Oral Med Oral Pathol. 1998; 85:86-93. [PMID: 9474621]

9. Sundquist G, Figdor D. Life as endodontic pathogen. Ecological differences between the untreated and filled root canals. Endod Topics. 2003; 6:3-28. [DOI: 10.1111/j.1601-1546.2003.00054.X]

10. Heid CA, Stevens J, Lival KJ, Williams PM. Real-time quantitative PCR. Genome Res 1996; 6: 986-994. [PMID: 8908518]

11. Gomes BP, Pinheiro ET, Gade-Net CR, EL Sousa, Ferraz CC, Zaia AA, et al. Microbiological examination of infected dental root canals. Oral Micromiol Immunol. 2004; 19:71-6. [PMID: 14871344]

12. Gomes BP, Pinheiro ET, Jacinto RC, Zaia AA, CC Ferraz, de SouzaFilho F). Microbial analysis of canals of root filled teeth with periapical lesions using polymerase chain reaction J Endod 2008; 34:537-40. [DOI: 10.1016 / j.joen.2008.01.016] [PMID: 18436030]

13. Rocas IN, Jung II-Y, C-Y Lee, Siqueira JFJr. Polymerase chain reaction identification of microorganisms in previously root-filled teeth and the South Korean population. I Endod. 2004; 30:504-8. [PMID: 15220647]

14. Sedgley C, Nagel A, Dahlen G, C Reit, Molander A. Real-time quantitative polymerase chain reaction analysis and culture of Enterococcus faecalis in root canals. J Endod. 2006; 32: 173-177. [DOI: 10.1016/j.joen.2005.10.037] [PMID: 16500220]

15. Sakamoto M, Siqueira JFJr, Rocas IN, Benno Y. Molecular analysis of the root canal microbiota associated with endodontic treatment failures Oral Microbiol Immunol 2008; 275-281.

[DOI: 10.1111 / j.1399-302X.2007.00423.x] [PMID: 18582326]

16. Kaufman B, Spangberg L, Barry J, Fouad AF. Enterococcus spp in endodontically treated teeth with or without periradicular lesions. J Endod 2005; 31:851-6. [PMID: 16306816]

17. Zoletti GO, Siqueira JFJr, Santos KR. Identification of Enterococcus faecalis in root-filled teeth with or without periradicular lesions by culture-dependent and independent approaches. J Endod. 2006; 32:722-6. [DOI: 10.1016/j.joen.2006.02.001] [PMID: 16861069]
18. Liang Y-H, Li G, Wesselink PR, Wu M-R. Endodntic outcome predictors identified with periapical radiographs and conebeam computed tomography scans. I Endod. 2011; 37:326-31. [DOI: 10.1016/j.joen.2010.11.032] [PMID: 21329816]

19. Schirrmeister JF, Liebenow A-L, Breun G, A Wittmer, Hellwing E, Al-Ahmad. A detection and eradiction of microorganisms in root-filled teeth associated with periradicular lesions: an in vivo study. Endod. 2007; 33:536-40. [DOl: 10.1016/j.joen.2007.01.012] [PMID: 17437867]

20. Love RM. Enterococcus faecalis- a mechanism for its role in endodontic failure Int Endod J. 2001; 34:399-405. [PMID: 11482724 ]

21. Evans M, JK Davies, G Sundquist, Figdor D. Mechanisms involved in the resistance of Enterococcus faecalis to calcium hydroxide. Int Endod J. 2002; 35:221-8. [PMID: 1198567]

22. Fabricius L, Dahl G, Holm SC, Möller $\AA$ Jr. Influence of combination of oral bacteria on periapical tissues on monkeys. Scand J Dent Res. 1982; 90:200-6. [DOI: 10.1111/j.1600-0722.2006.00380.x] [PMID: 16911098]

23. Stuart CH, Schwartz SA, Beeson TJ, Owatz CB. Enterococcus faecalis: its role in root canal treatment failure and current concepts and retreatment. J Endod. 2006; 32: 93-8. [DOI: 10.1016/j.joen.2005.10.049] [PMID: 16427453]

24. Williams JM, Trope M, Caplan DJ, Shugars DC. Detection and quantification of Enterococcus faecalis by Real-time PCR ( reverse transcription-PCR (RT-PCR), and Cultivation during endodontic treatment.) Endod. 2006; 32:715-21. [DOI: 10.1016/j.joen.2006.02.031] [PMID: 16861068]

25. Ruan Y, Shen L, Zou Y, Z Qi, Yin J, Jiang J, et al. Comparative genome analysis of Prevotella intermedia strain isolated from infected root canal reveals features related to pathogenicity and adsptstion. BMS Genomics. 2015; 16:122-7. [DOI: 10.1186/s12864-015-1272-3]

26. Oliviera JCM, Siqueira JFJr, Alves GB, RJF Hirata, Andrade AFB. Detection of Porphyromonas endodontalis in infected root canals by 165 rRNA generator directed polymerase chain reaction. I Endod. 2000; 26:729-32. [DOI: 10.1097/00004770-200012000-00016] [PMID: 11471643]

27. ET Pinheiro, BPFA Gomes Ferraz CCR, ELR Sousa, PB Texeira, Souza -Filho FJ. Microorganisms from canals of root filled teeth with periapical lesions. Int Endod J. 2003; 36:1-11. [PMID: 12656508]

Received: 17.08.2018 • Accepted: Prihvaćen 08.10.2018 


\title{
Mikrobiološki status kanala korena endodontski neuspešno lečenih zuba
}

\author{
Jelena Nešković1, Milica Jovanović-Medojević1, Đurica Grga'1, Branka Popović², Slavoljub Živković1 \\ 'Univerzitet u Beogradu, Stomatološki fakultet, Klinika za bolesti zuba, Beograd, Srbija; \\ ${ }^{2}$ Univerzitet u Beogradu, Institut za humanu genetiku, Stomatološki fakultet, Beograd, Srbija
}

\begin{abstract}
KRATAK SADRŽAJ
Uvod Osnovni zadatak endodontskog tretmana je da eliminiše infekciju iz kanala korena i spreči reinfekciju trodimenzionalnom hermetičkom opturacijom kanalskog sistema. Usled nemogućnosti potpune kontrole i eliminacije infekcije iz kanala korena može doći do pojave endodontskog neuspeha.

Cilj ovog rada je bio da se neposredno posle uklanjanja materijala za opturaciju kod zuba sa neuspelim endodontskim lečenjem PCR tehnikom proveri mikrobiološki status endodontski lečenih zuba.

Metode Mikrobiološka studija je obuhvatila 30 zuba (osam višekorenih i 22 jednokorena) indikovanih za ponovljeni endodontski tretman. Posle dezinfekcije radnog polja i dezopturacije koja je urađena isključivo mehaničkim putem, uzorak je uzet sterilnim kanalnim instrumentom tipa pulpekstirpatora (\#15) ili Hoedstrem-turpije (\#15) i uz pomoć papirnih poena kojima je sušen kanal. Ependorfice su čuvane na temperaturi od $-20^{\circ} \mathrm{C}$ do mikrobiološke analize. Putem klasičnog PCR analizirana je zastupljenost bakterija: Enterococcus faecalis, Peptostreptococcus micros, Prevotela intermedia, Porphyromonas endodontalis i Actinobacilus actinomycetemcomitans. Rezultati Pozitivan bakteriološki nalaz registrovan je u $80 \%$ slučajeva, dok bakterije nisu identifikovane u $20 \%$ uzoraka. Svi negativni uzorci su uzeti iz kanala korena zuba bez značajnih promena u apeksnom periodoncijumu, dok je 17 od 24 kanala sa identifikovanim bakterijama pripadalo zubima sa oštećenim apeksnim parodoncijumom. Najprisutniji mikroorganizam u kanalima sa pozitivnim bakteriološkim nalazom bio je E. faecalis, koji je identifikovan u 83,3\% kanala, zatim P. inermedia sa $75 \%$ i $P$. micros sa zastupljenošću od $58,3 \%$. Kod zuba sa hroničnim periapikalnim promenama najzastupljeniji je bio E. faecalis, koji je identifikovan u $94 \%$ kanala, zatim P. intermedia, koja je bila prisutna u 82,3\% uzoraka. Mikroorganizmi E. faecalis i P. intermedia su registrovani kod svih pacijenata sa nekim od simptoma.

Zaključak Prisustvo periapikalnih lezija značajno utiče na mikrobiološki status kanala korena endodontski lečenih zuba. Prisustvo bakterija u kanalima korena potvrđeno je u većini endodontski neuspešno lečenih zuba, a najčešće identifikovane bakterije bile su E. faecalis, zatim P. intermedia, P. micros i P. endodontalis.

Ključne reči: PCR; E. faecalis; endodontski neuspeh
\end{abstract}

\section{UVOD}

Osnovni zadatak endodontskog tretmana je da eliminiše infekciju iz kanala korena i prevenira reinfekciju trodimenzionalnom hermetičkom opturacijom kanalskog sistema. Ponekad, međutim, i kod adekvatno sprovedenog endodontskog tretmana može doći do endodontskog neuspeha.

Potvrđeno je da ishod endodontskog tretmana umnogome zavisi od kvalitetno realizovane endodontske procedure i mogućnosti eliminacije infekcije iz kanalnog sistema korena pre opturacije $[1,2]$. Zbog kompleksnosti kanalskog sistema njegovo čišćenje je prilično otežano pa bakterije mogu zaostati u nepristupačnim delovima kanala na svim njegovim nivoima, a naročito u apeksnom delu.

Intraradikularna infekcija koja perzistira u kompleksnoj apikalnoj trećini kanalnog sistema korena najčešće je posledica neadekvatno sprovedenog endodontskog tretmana, odnosno neaseptičnih uslova rada sa nedovoljno ekstendiranim i loše dizajniranim pristupnim kavitetom, kao i nedovoljne dimenzije instrumentacije, neadekvatne hermetične opturacije ili mikrocurenja usled neadekvatnog privremenog ili definitivnog ispuna [3].

Međutim, određeni broj lezija u periapeksu može da perzistira kao asimptomatsko radiografsko rasvetljenje čak i pored adekvatno realizovane endodontske procedure. Razlog je najčešće kompleksna anatomija kanalnog sistema sa regijama koje se ne mogu adekvatno ni obraditi niti opturisati postojećim instrumentima, materijalima i tehnikama [4]. Neke studije su pokazale da određeni delovi kanalnog prostora korena zuba ostaju netaknuti tokom hemomehaničke instrumentacije bez obzira na to koja se tehnika preparacije i kanalni instrumenti koriste [5]. Netaknute regije endodontskog prostora mogu sadržati bakterije i nekrotično tkivo čak i onda kada se čini da je opturacija kanala radiografski korektna [4]. Smatra se da do endodontskog neuspeha dolazi usled nemogućnosti potpune kontrole i eliminacije infekcije u kanalu korena.

Cilj ovog rada je bio da se neposredno posle uklanjanja materijala za opturaciju kod zuba sa neuspelim endodontskim lečenjem PCR tehnikom proveri mikrobiološki status endodontski lečenih zuba.

\section{METODE}

Materijal za mikrobiološka ispitivanja dobijen je uzimanjem uzoraka iz 30 endodontski lečenih kanala korena zuba kod kojih je postojala potreba za retretmanom. Kod svih pacijenata uzeti su anamnestički podaci, urađeni su klinički pregled i detaljna analiza retroalveolarne radiografije i na osnovu toga postavljana dijagnoza neuspeha inicijalnog endodontskog tretmana.

Mikrobiološka studija je obuhvatila 30 zuba (osam višekorenih i 22 jednokorena) indikovanih za ponovljeni endodontski tretman. Primarna endodontska terapija je u dva slučaja bila sprovedena pre 12 meseci, u osam slučajeva u periodu 1-5 godina, dok je kod 20 zuba primarno endodontsko lečenje bilo urađeno pre više od pet godina. Svih 30 zuba imalo je radiografski nalaz sa neadekvatnom opturacijom jer je to bio kriterijum neuspeha zbog kojeg su pacijenti i upućeni na ponovni endodontski tretman. Nezadovoljavajući nivo kvaliteta opturacije je ocenjen kao kratko punjenje (22 zuba), kao „zaboravljeni“ kanal (sedam zuba), odnosno kanal sa zalomljenim instrumentom (jedan 
zub). Kod 13 zuba uočena je adekvatna restauracija ili protetska nadoknada, sedam zuba je bilo bez ispuna duži period, a 10 zuba nije imalo odgovarajući ispun. Prisustvo simptoma u vidu bola, otoka, prisustva fistule, osetljivosti na perkusiju ili bolovi na zagrižaj zabeleženi su kod 10 pacijenata, dok preostalih 20 nije imalo kliničke znake ni simptome.

Zdravlje apeksnog periodoncijuma ocenjivano je dodeljivanjem PAI indexa, pri čemu je potpuno zdrav parodoncijum (PAI 1) radiografski registrovan u šest slučajeva; PAI 2 skor (male promene u strukturi kosti koje nisu patognomonične za apikalni periodontitis) zabeležen je u sedam slučajeva; PAI 3 skor (koji podrazumeva promene u koštanoj strukturi sa dekalcifikacijom karakterističnom za apikalni periodontitis) registrovan je kod 13 zuba; PAI 4 (koji predstavlja periodontitis sa jasno definisanom zonom rasvetljenja) zabeležen je u tri slučaja, i najviši PAI 5 skor (uznapredovao periodontitis sa znacima egzacerbacije i ekspanzije kosti) dodeljen je samo jednom slučaju.

Mikrobiološki postupak je uključivao najpre uklanjanje čvrstih i mekih naslaga sa zuba, eventualno postojećih restauracija i karijesnih masa i postavljenje koferdama. Dezinfekcija operativnog polja urađena je 30\% rastvorom vodonik-peroksida i 2,5\% rastvorom natrijum-hipohlorita, koji je zatim inaktivisan 5\% rastvorom natrijum-tiosulfata. Dezopturacija je urađena isključivo mehanički bez upotrebe bilo kakvih rastvarača, lubrikanata ili iriganasa. Gates-Glyden svrdlima je gutaperka uklonjena iz prve dve trećine kanala, a hoedstrem turpijama iz apikalne trećine kanala korena zuba. Tokom radiografskog postupka odontometrije kontrolisan je kvalitet uklanjanja materijala za opturaciju. Odontometrija je potvrđivana elektroodontometrom. U slučajevima zaboravljenih kanala ekstendiran je pristupni kavitet, korigovana trepanacija i locirani ulazi, a kanali su instrumentirani modifikovanom tehnikom dvostrukog konusa Gates-Glyden svrdlima i ručnim hoedstrem i k-flex turpijama do pune radne dužine. Veličina apeksne preparacije (ISO \#25 ili \#30) zavisila je od inicijalnog promera i povijenosti kanala korena zuba. Zatim je mala količina sterilnog fiziološkog rastvora ubrizgana u kanal tako da se isti ne prepuni. Kanal je potom dodatno instrumentiran kako bi se sastrugao materijal sa zidova kanala. Uzorak je uzet sterilnim kanalnim instrumentom tipa pulpekstirpatora (\#15) ili hoedstrem turpije (\#15) i uz pomoć papirnih poena kojima je sušen kanal. Papirni poeni su plasirani sterilnom pincetom, ostavljeni u kanalu tokom 60 sekundi, a zatim postavljeni u sterilne ependorfe zajedno sa kanalnim istrumentima čija je drška odsečena sterilnim kleštima. Ependorfice su čuvane na temperaturi od $-20^{\circ} \mathrm{C}$ do mikrobiološke analize.

Sa ciljem da se izoluje DNK, u svaku mikrotubu papirnim poenom dodato je $100 \mu \mathrm{l}$ redestilovane $\mathrm{H}_{2} \mathrm{O}$. Za izolaciju totalne bakterijske DNK (gram-pozitivne i gram-negativne bakterije) korišćen je komercijalni kit Qiamp DNA Mini Kit (Qiagen). Posle primenjenog protokola za izolaciju bakterijska DNK je rastvorena u $100 \mu$ l pufera za eluciju.

Putem klasičnog PCR analizirana je zastupljenost bakterija: Enterococcus faecalis, Peptostreptococcus micros, Prevotela intermedia, Porphyromonas endodontalis i Actinobacilus actinomycetemcomitans. Sekvence korišćenih prajmera, temperaturni profil i dužine PCR produkata date su u Tabeli 1. U svakoj PCR reakciji istovremeno sa testiranim uzorcima korišćene su pozitivne i negativne kontrole, da bi se izbegli lažno pozitivni i negativni rezultati. Reakcion smešu PCR reakcije, volumena 25

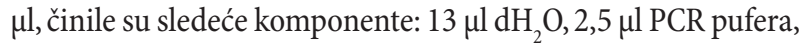

$1,5 \mu \mathrm{l} 25 \mathrm{mM} \mathrm{MgCl}, 1 \mu \mathrm{ldNTP}$, po $1 \mu \mathrm{l} \mathrm{F}$ i R prajmera, $0,2 \mu \mathrm{l} \mathrm{Taq}$ polimeraze i $5 \mu$ l bakterijske DNK.

Uspešnost PCR reakcije je proveravana vertikalnom elektroforezom na $8 \%$ poliakrilamidnom gelu (PAA) u 1XTBE-puferu, pri konstantnom naponu struje od $200 \mathrm{~V}$, u trajanju od $30 \mathrm{~min}$. Vizuelizacija PCR produkata urađena je putem bojenja etidijum bromidom.

\section{REZULTATI}

PCR analizom je ispitivano prisustvo sledećih mikroorganizama: Enterococcus faecalis, Peptostreptococcus micros, Prevotela intermedia, Porphyromonas endodontalis i Actinobacilus actinomicetemcomitans.

Pozitivan bakteriološki nalaz registrovan je u $80 \%$ slučajeva, dok bakterije nisu identifikovane u 20\% uzoraka. Svi negativni uzorci su uzeti iz kanala korena zuba bez značajnih promena u apeksnom periodoncijumu (PAI 1,2) dok je 17 od 24 kanala sa identifikovanim bakterijama pripadalo zubima sa oštećenim apeksnim parodoncijumom (PAI 3, 4, 5) (Tabela 2). Svi uzorci uzeti iz kanala korena zuba sa hroničnim periapikalnim lezijama su bili pozitivni na prisustvo bakterija (100\%).

Kada je u pitanju zastupljenost ispitivanih bakterijskih vrsta, najčešće identifikovana bakterija bila je E. faecalis $(66,6 \%)$, potom P. intermedia (60\%), P. micros (46,6\%), P. endodontalis (26,6\%) i A. actinomycetemcomitans (10\%) (Tabela 3).

Najprisutniji mikroorganizam u kanalima sa pozitivnim bakteriološkim nalazom bio je E. faecalis, koji je identifikovan u $83,3 \%$ kanala, zatim $P$. inermedia sa $75 \%$ i $P$. micros sa zastupljenošću od 58,3\% (Tabela 4). U grupi zuba sa zdravim apeksnim parodoncijumom sve bakterijske vrste (izuzev A. actinomycetemcomitans, koji nije detektovan ni u jednom uzorku) bile su jednako zastupljene, odnosno identifikovane su u 57,7\% kanala. Kod zuba sa hroničnim periapikalnim promenama najzastupljeniji je bio E. faecalis, koji je identifikovan u 94\% kanala, zatim $P$. Intermedia, koja je bila prisutna u $82,3 \%$ uzoraka (Tabela 4).

Kada je u pitanju broj bakterijskih vrsta prisutnih u pojedinačnom uzorku, samo u 13,3\% slučajeva se radilo o monoinfekciji (u polovini takvih kanala u pitanju je bio E. faecalis), dok su najčešće $(33,3 \%$ kanala) identifikovane tri bakterijske vrste $\mathrm{u}$ kanalu korena (E. faecalis, P. intermedia i P. micros) (Tabela 5).

Uočeno je da uzorci uzeti iz zuba sa zdravim parodontalnim tkivima oko vrha korena pokazuju uglavnom odsustvo bakterija ili prisustvo jedne ili dve bakterijske vrste, dok je u slučaju postojanja hroničnih periapikalnih promena u više od polovine uzoraka identifikovano prisustvo tri ili više bakterijskih vrsta (Tabela 6).

Korelacija između prisustva određenih simptoma posle primarnog endodontskog lečenja i nalaza određenih bakterijskih vrsta u kanalu korena prikazana je u Tabeli 7.

Mikroorganizmi $E$. faecalis $i$ P. intermedia su registrovani kod svih pacijenata sa bolovima, kod zuba osetljivih na perkusiju i bolove pri zagrižaju, kao i kod polovine uzoraka uzetih iz kanala korena zuba sa otokom i fistulom.

Peptostreptococcus micros je identifikovan kod 66,6\% pacijenata sa bolom, kod 50\% pacijenata sa otokom, fistulom i perkutornom osetljivošću i kod 33,3\% pacijenata sa prisutnim bolovima na zagrižaj. Prisustvo $P$. endodontalis je potvrđeno u 33,3\% kanala sa registrovanim spontanim bolovima i $25 \%$ kanala sa perkutornom osetljivošću. Najređe identifikovani 
mikroorganizam bio je A. actinomyces, koji je identifikovan u 50\% kanala sa prisutnom fistulom, kod 33,3\% pacijenata sa bolovima na zagrižaj i 12,5\% uzoraka uzetih iz kanala korena zuba pacijenata sa osetljivošću pri perkusiji (Tabela 7).

\section{DISKUSIJA}

U analizu je uključeno 30 zuba kod kojih je postojala potreba za retretmanom bez obzira na to da li je u pitanju bila protetska indikacija, slučajan nalaz ili je pacijent imao određene tegobe.

Kako bi se sprečila kontaminacija uzoraka iz kanala, sprovođeni su striktno aseptični uslovi uzimanja i aktuelni protokol dezinfekcije radnog polja [6-9]. To je podrazumevalo dekontaminaciju radnog polja i dezinfekciju operativnog polja $30 \%$ rastvorom vodonik-peroksida i 2,5\% rastvorom natrijum-hipohlorita i potom inaktivaciju $5 \%$ rastvorom natrijum-tiosulfata kako njegovi ostaci ne bi uticali na uzeti uzorak [7]. Takođe, kompletna dezopturacija je rađena isključivo mehanički bez upotrebe bilo kakvih rastvarača, lubrikanata ili iriganasa. Mikrotube sa mikrobiološkim materijalom su čuvane na temperaturi od -20 C, ne duže od mesec dana.

PCR (Polymerase Chain Reaction) savremena je, brza (potrebno je svega nekoliko sati) i jednostavna metoda za identifikaciju mikroorganizama. Izuzetno je osetljiva i visoko specifična. Teoretski je moguće dokazati prisustvo samo jedne bakterijske ćelije (žive ili mrtve) u uzorku, mada se broj od 10 ćelija smatra donjom granicom detekcije (primera radi, za metodu kultivisanja bakterija neophodno je 100 živih ćelija) [9]. Identifikacija se zasniva na in vitro amplifikaciji ciljnog fragmenta DNK, koju je moguće ponoviti i do milijardu puta. Zahvaljujući tome što se detekcija radi na osnovu genotipske strukture, a ne fenotipskih karakteristika mikroorganizama, identifikacija je vrlo pouzdana i precizna. Moguće je identifikovati i one bakerijske vrste koje se ne mogu kultivisati in vitro ili slučajeve kada je broj ćelija u ispitivanom materijalu jako mali [9].

Međutim, PCR metoda identifikacije mikroorganizama ima i svoja ograničenja. Na prvom mestu, vrste koje nisu otkrivene nekom drugom metodom i vrste koje se ciljano ne traže ne mogu se ni detektovati. Postavljaju se tačno determinisani uslovi izvođenja reakcije sa određenim parom prajmera koji mogu da detektuju samo tu, specifičnu, bakterijsku vrstu. Treba naglasiti da PCR metoda ne prepoznaje da li je identifikovana ćelija živa ili mrtva. Drugo ograničenje konvencionalne PCR metode odnosi se na nemogućnost apsolutne kvantifikacije prisutnih bakterija. Ovo se može prevazići „real-time“ PCR metodom, gde se može utvrditi i broj bakterijskih ćelija [10].

Pozitivan bakteriološki nalaz registrovan je u $80 \%$ slučajeva, dok bakterije nisu identifikovane u 20\% uzoraka. Svi uzorci uzeti iz kanala korena zuba sa hroničnim periapikalnim lezijama su bili pozitivni na prisustvo bakterija (100\%). Takođe, svi negativni uzorci su uzeti iz kanala korena zuba sa zdravim parodoncijumom. $\mathrm{Na}$ taj način je potvrđena hipoteza da bez bakterija nema infekcije u periapikalnim tkivima, a samim tim ni neuspeha endodontskog lečenja. Slične rezultate dobili su Siqueira i sar. [5], Gomes i sar. [11, 12], Rôças i sar. [13], Sedgley i sar. [14], Sakamoto i sar. [15].

Međutim, 23\% bakteriološki pozitivnih uzoraka uzeto je iz kanala korena zuba čije je stanje apeksnog parodoncijuma ocenjeno vrednošću PAI indexa 2, što radiografski predstavlja blago proširen periodontalni prostor bez znakova patognomoničnih za hronična zapaljenja apeksnog parodoncijuma. Kaufman i sar. [16] i Zoletti i sar. [17] takođe su registrovali prisusutvo bakterija u kanalima korenova zuba bez radiografski uočljivih periapikalnih promena. Objašnjenje može ležati u činjenici da retroalveolarna radiografija nije dovoljno precizna u dijagnozi apeksnog parodontitisa sa manjim destrukcijama koštanih tkiva [18]. Drugi razlog za prisustvo bakterija u kanalu korena bi mogao biti mali broj i slaba virulencija bakterija. Da bi mikroorganizmi koji su opstali nakon primarnog endodontskog lečenja kanala korena izazvali ili održavali periradikularno zapaljenje, moraju biti dovoljno patogeni i u dovoljno velikom broju [2].

Kada se govori o bakterijama prisutnim u kanalima korena zuba sa periapikalnim promenama posle endodontskog lečenja, nameće se dilema da li su one zaostale posle primarnog endodontskog tretmana (perzistirajuća infekcija) ili su posledica reinfekcije (sekundarna infekcija). Poslednjih godina su istraživači ukazivali na značaj koronarne restauracije u prevenciji reinfekcije endodontskog prostora i izneli stav da je sekundarna infekcija važan uzročnik neuspeha endodontskog lečenja $[1,19]$.

Najzastupljeniji mikroorganizam u kanalima sa pozitivnim bakteriološkim nalazom bio je E. faecalis, zatim P. intermedia i P. micros sa zastupljenošću od 58,3\%.E. faecalis je identifikovan u 94\% kanala korena zuba sa hroničnim periapikalnim lezijama (PAI 3, 4, 5), što je slično nalazima Sledgley i sar., koji su takođe PCR metodom identifikacije na 48 uzoraka dobili $90 \%$ učestalost ovog gram-pozitivnog mikrorganizma [14]. Gomes i sar. su PCR-om analizirali mikrobiološki status prethodno punjenih kanala sa periapikalnim lezijama i došli do zaključka da je $E$. faecalis prisutan u $90 \%$ bakteriološki pozitivnih kanala, potom slede P. micros - 59\%, P. gingivalis - 41\%, P. endodontalis - $26 \%$ i P. intermedia - 13\% [12].

Ovako visok procenat prisustva E. faecalisa verovatno je posledica njegovih brojnih i raznovrsnih faktora virulencije $\mathrm{i}$ izuzetne sposobnosti preživljavanja. Ovaj mikroorganizam je dovoljno mali i lako prodire u dentinske tubule, a ima i dobru sposobnost adherencije za kolagen [20]; rezistencije na kalcijum-hidroksid [21]; sposobnost da preživi (kao jedina vrsta) u dentinskim kanalićima kanala bez podrške drugih bakterija [22]; sposobnost da preživi bez ishrane i oporavi se čim nutritijenti u vidu seruma (porekla alveolarne kosti i periodontalnog ligamenta) postanu dostupni [23].

Rezultati ove studije potvrđuju prisustvo E. faecalisa u $57,7 \%$ kanala korena zuba bez promena u apeksnom parodoncijumu. Medutim, P. intermedia, P. endodontalis i P. micros su takođe identifikovane u 57,7\% kanala, što navodi na zaključak da $E$. faecalis nije jedini mikroorganizam odgovoran za neuspeh endodontskog tretmana. Williams i sar. su pokazali da $E$. faecalis može da preživi sve etape endodontskog tretmana jer su RT-PCR-om detektovali njegovo prisustvo u uzorcima uzetim neposredno posle instrumentacije i irigacije, kao i posle interseansne medikacije [24].

Ovo istraživanje ukazuje na to da su preostali mikroorganizmi verovatno dospeli u kanal zahvaljujući neadekvatnom kruničnom zaptivanju. Naime, kod 70\% zuba sa zdravim apeksnim parodoncijumom krunične restauracije nisu bile zadovoljavajućeg kvaliteta, što predstavlja ulazna vrata za sekundarnu infekciju endodontskog prostora. Međutim, iako prisutne u kanalu korena, ove bakterije nisu imale uticaja na periradikularna tkiva. Prvi razlog bi mogao biti da su ostale blokirane i zarobljene u dentinskim kanalićima materijalom za definitivnu opturaciju kanala, a 
drugi da je na njihovom putu od usne duplje (mikrocurenjem) kanalno punjenje blokiralo dalji prolaz ka periapeksnim tkivima.

Pacijenti koji su uzeli učešća u ovoj studiji su dolazili iz ordinacija opšte stomatološke prakse i domova zdravlja, gde je mogućnost poštovanja savremenih standarda i dobre endodontske prakse uglavnom neadekvatna, tako da je učestalost bakterija zaostalih posle primarnog endodontskog lečenja mogla biti visoka (kako za $E$. faecalis tako i za druge mikroorganizme).

Prevotella spp i Porphiromonas spp (ranije klasifikovani kao Bacteroides spp) pripadaju grupi „crnopigmentisanih bakterija“ jer na agaru formiraju sjajne, glatke kolonije sive ili crne boje. Po novoj taksonimiji, saharolitične vrste Bacteroides spp su svrstane u rod Prevotella, a asaharolitične u rod Porphiromonas. Vrste $P$. intermedia, $P$. melaninigenica, $P$. denticola i $P$. dentalis pripadaju gram-negativnim obligatnim anaerobima. Iako imaju ograničenu sposobnost fermentacije aminokiselina i zahtevaju prisustvo hemina i menadoina za rast, mogu se uočiti u različitim delovima organizma (usna duplja, gornji respiratorni i urogenitalni trakt) [25]. Ruan i sar. su ustanovili da Prevotella intermedia poreklom iz usne duplje predstavlja potencijalno oportunistički mikroorganizam koji se povezuje sa periodontalnim oboljenjima ali i sa periapikalnim periodontitisom jer poseduje adhezivnost $i$ kompetitivnost sa okolnim mikroorganizmima [25].

Porphyromonas endodontalis je gram-negativan mikroorganizam koji se dovodi u vezu sa periodontitisom, endodontskom infekcijom i gingivitisom, i to češće sa simptomatskim nego asimptomatskim infekcijama u usnoj duplji [26].

Trećina pacijenata koji su uzeli učešća u studiji su prijavali neki od kliničkih simptoma, a najčešće registrovani simptom bila je osetljivost na perkusiju. Najčešće prisutni mikroorganizmi u uzorcima uzetih iz takvih kanala su bili E. faecalis i P. intermedia (100\%), a zatim P. micros (50\%). Gomes i sar. su takođe našli statistički značajnu povezanost $P$. microsa i osetljivosti zuba na perkusiju [12], a Pinheiro i sar. su sa ovim simptomom povezali prisustvo $P$. intermedia [27].

E. faecalis $i$ P. intermedia su registrovani kod svih pacijenata sa bolovima, osetljivošću na perkusiju i bolovima na zagrižaj, kao i kod polovine uzoraka uzetih iz kanala korena zuba pacijenata sa otokom i fistulom. P. micros je identifikovan kod 66,6\% pacijenata sa bolom, a Pinheiro i sar. ovo takođe povezuju sa prisusutvom bakterijskih vrsta $P$. intermedia i P. micros [27].

\section{ZAKLJUČAK}

Prisustvo periapikalnih lezija značajno utiče na mikrobiološki status kanala korena endodontski lečenih zuba. Prisustvo bakterija u kanalima korena potvrđeno je u većini endodontski neuspešno lečenih zuba, a najčešće identifikovane bakterije bile su E. faecalis, zatim P. intermedia, P. micros i P. endodontalis. 